\title{
Tracking changes in relative body composition of southern elephant seals using swim speed data
}

\author{
Michele Thums $^{1, *}$, Corey J. A. Bradshaw ${ }^{2,3}$, Mark A. Hindell ${ }^{1}$ \\ ${ }^{1}$ Antarctic Wildlife Research Unit, School of Zoology, University of Tasmania, Private Bag 05, Hobart, \\ Tasmania 7001, Australia \\ ${ }^{2}$ Research Institute for Climate Change and Sustainability, School of Earth and Environmental Sciences, \\ University of Adelaide, Adelaide, South Australia 5005, Australia \\ ${ }^{3}$ South Australian Research and Development Institute, PO Box 120, Henley Beach, South Australia 5022, Australia
}

\begin{abstract}
Changes in buoyancy during an animal's time at sea are a powerful tool for inferring spatial and temporal foraging success. Buoyancy can be difficult to measure, but in some species of seal, drift components of dives can be used. We used swim speed data from adult female southern elephant seals Mirounga leonina using geo-locating velocity-time-depth recorders during 2004 postlactation (PL; $\mathrm{n}=7$ ) and 2002, 2004 and 2005 post-moult $(\mathrm{PM} ; \mathrm{n}=18)$ foraging trips to detect periods of passive drifting during diving. In addition to the characteristic drift dives of elephant seals, drifting also occurred during putative foraging dives. We used generalised linear models (GLMs) to examine the relationship between body lipid content measured on land and several diving variables collected within a week of these measurements being taken. The strongest support (deviance explained = $90 \%)$ was for the model including drift rate $(77 \%)$, seal length $(12 \%)$ and descent rate $(2 \%)$. Estimates of body lipid, based on the GLM, were predicted for each day of the foraging trips. Areas where seals increased their relative lipid content from one day to the next corresponded well with areas in which the seals spent the greatest amount of time. Inferring foraging success from positive changes in drift rate has so far been limited to elephant seals which perform characteristic drift dives, but the addition of swim speed data to detect short periods of stationary behaviour allows for this method to be expanded to a greater range of ocean predators.
\end{abstract}

KEY WORDS: Foraging success · Buoyancy $\cdot$ Lipid content $\cdot$ Mirounga leonina $\cdot$ Southern Ocean Swim speed $\cdot$ Antarctica

Resale or republication not permitted without written consent of the publisher

\section{INTRODUCTION}

Apex predators are thought to play key roles in determining marine food web structure and ecosystem dynamics (Pace et al. 1999, Bascompte et al. 2005, Myers et al. 2007), although generally little is known about where and when such predators encounter and capture prey. Such spatially explicit information is fundamental for modelling the trophic structure of marine ecosystems (Constable et al. 2000, Thomson et al. 2000) because estimates of the spatial and temporal variation in prey consumption are required to predict energy flow through the food web (Hindell et al. 2003).
Given the difficulty of directly observing marine predator foraging behaviour, many proxies have been developed to infer foraging activity, e.g. movement pattern analysis (Le Boeuf et al. 2000, Pinaud \& Weimerskirch 2005, Fauchald \& Tveraa 2006, Tremblay et al. 2007) and spatially explicit time summaries (Bost et al. 1997, Guinet et al. 2001, Hindell et al. 2003, Bradshaw et al. 2004). Although such broad-scale inferences of foraging behaviour are useful, they do not necessarily provide good approximations of where foraging is successful (i.e. prey is ingested). Prey ingestion has been estimated for a number of marine predators by measuring changes in stomach or oesophageal temperature (Bekkby \& Bjorge 1998, Lesage et al. 
1999, Charrassin et al. 2001, Austin et al. 2006, Horsburgh et al. 2008), monitoring jaw movements using intra-mandibular angle sensors (Wilson et al. 2002, Simeone \& Wilson 2003, Liebsch et al. 2007) or by video and image recording (Davis et al. 1999, Bowen et al. 2002, Hooker et al. 2002, Sato et al. 2002). However, stomach temperature and mandibular-angle telemetry is restricted by the difficulty of ensuring the sensors remain in or on the animal for sufficient duration (Wilson et al. 1998, Austin et al. 2006) to infer foraging success over broad spatial and temporal scales. Similarly for video and image recording, the requirement for large onboard memory limits the ability to obtain enough data over longer time scales. Correlating these direct measures of feeding with behavioural variables such as burst of swim speed or dive depth profile undulations recorded by time-depth recorders can also be used as proxies for feeding (Simeone \& Wilson 2003, Bost et al. 2007, Hassrick et al. 2007, Horsburgh et al. 2008), but none of these methods can estimate potential energy assimilation (Biuw et al. 2003).

An alternative approach is the inference of foraging success based on surrogate measures of in situ body composition (Biuw et al. 2003, 2007, Bailleul et al. 2007). During their time at sea, many marine mammals, and particularly phocid seals, accumulate large quantities of prey-derived lipid (Fedak et al. 1994) which they store in body tissues, the majority $(\sim 84 \%)$ of which is stored in the blubber (Slip et al. 1992). On land, changes in body composition can be measured with relative ease (Boyd et al. 1993, Beck et al. 2000, Field et al. 2007), allowing for an estimate of gross body condition and mass gain over entire foraging trips. However, for species migrating long distances and spending months at sea (e.g. elephant seals Mirounga spp.), estimates of average mass/fat gain from onshore measurements necessarily assume a constant rate of gain over the interval investigated. This is unrealistic because there will inevitably be periods of loss and gain throughout the time at sea as predators fail or succeed in finding and exploiting prey patches of variable quantity and quality (Biuw et al. 2007).

Fluctuations in body composition at sea lead to measurable fluctuations in buoyancy, which can be detected in an individual's diving behaviour (Crocker et al. 1997, Webb et al. 1998). In pinnipeds, buoyancy is determined largely by the relative proportions of lipid and lean body tissue (Webb et al. 1998, Beck et al. 2000); individuals with a high lipid:lean tissue ratio are more buoyant than individuals of similar mass but with lower proportional lipid stores (Beck et al. 2000, Biuw et al. 2003). To date, changes in buoyancy have been estimated from drift dives identified from time-depth profiles indicating the cessation of active swimming and passive vertical drift in the water column (Crocker et al. 1997). In elephant seals, drift rates have been used successfully as proxies for relative body composition changes in free-ranging individuals (Biuw et al. 2003), providing a time series of foraging success throughout an individual's time at sea (Biuw et al. 2003, 2007, Bailleul et al. 2007).

Past studies have assessed drift dives using visual classification (Hindell et al. 1991b, Crocker et al. 1997, Le Boeuf et al. 2000). Whilst visual classification of drift dives probably has a low error rate given the dives' relatively characteristic and simple shape, it is not feasible for large datasets. Although statistical classification methods (Le Boeuf et al. 1992, Schreer \& Testa 1995, 1996, Schreer et al. 1998, Lesage et al. 1999, Baechler et al. 2002) or automated approaches to detect the putative drift phase (Biuw et al. 2003, 2007, Bailleul et al. 2007) can be employed, these methods may be prone to large errors.

In the present paper we identified drift dives made by adult female southern elephant seals Mirounga leonina using the independent variable of swim speed. Swim speed data from archival-tag turbines can identify periods of drift with more certainty than using dive shape alone, so these can be used to assess the changes in buoyancy that reflect changes in relative body lipid. We (1) used swim speed data collected via geo-locating velocity-time-depth recorders (VTDR) deployed on adult female seals during post-lactation $(\mathrm{PL} ; \mathrm{n}=7)$ and post-moult $\left(\mathrm{PM}_{;} \mathrm{n}=18\right)$ foraging trips to detect drifting and, thus, measured relative buoyancy, (2) developed a model predicting relative body lipid content throughout the course of the foraging trip using drift rate, other behavioural measurements and onshore estimates of body composition to quantify periods of relative lipid loss and gain, (3) assessed the temporal resolution over which relative body composition can be estimated, (4) allocated relative foraging success temporally and spatially during the 2 separate periods of foraging and (5) described the behavioural characteristics of the drifting dives and the temporal patterns in the changes in drift rates and relative body lipid content.

\section{MATERIALS AND METHODS}

Data collection. We instrumented known-age (born in 1993 and 1994) adult female southern elephant seals from Macquarie Island $\left(54^{\circ} 35^{\prime} \mathrm{S}, 158^{\circ} 58^{\prime} \mathrm{E}\right)$ with VTDRs (Wildlife Computers MK8) prior to the 2004 PL $(\mathrm{n}=12)$ and $2002(\mathrm{n}=14), 2004 \mathrm{PM}(\mathrm{n}=16)$ and 2005 $(\mathrm{n}=4)$ foraging trips. Seals were captured, sedated, weighed $( \pm 1 \mathrm{~kg})$, measured $( \pm 10 \mathrm{~mm})$ and assessed for body composition (using blubber depth measurements and other morphometric measurements) following the 
procedures outlined in Field et al. (2002). This was done on 2 occasions for each seal during the period ashore for breeding: (1) within $24 \mathrm{~h}$ post-parturition, (2) $21 \mathrm{~d}$ after parturition and on 2 occasions during the period ashore for moulting, (3) within $4 \mathrm{~d}$ of arrival premoult and (4) within $4 \mathrm{~d}$ of departure at the end of the moult. We did this to obtain an arrival and departure mass for each seal. The VTDRs were attached to the pelage above the shoulders following the procedures outlined in Hindell \& Slip (1997) and sampled time, depth, light level, revolutions of a flow-driven turbine mounted on top of the instrument and temperature every $30 \mathrm{~s}$ for the duration of both foraging trips. Daily at-sea positions were derived from the logged light levels using geo-location software provided by Wildlife Computers (WC-GPE: Global Position Estimator Program Suite). Positions were filtered using the interactive filter of McConnell et al. (1992). Speed was derived from the logged revolutions of the turbine using the post hoc calibration method outlined in Fletcher et al. (1996).

Data extraction and dive selection. Raw data from the VTDRs were extracted using software provided by Wildlife Computers. Summary parameters for each dive were then calculated using 'DIVE', a custom diveanalysis program (Stuart Greenhill, Murdoch University). These parameters included maximum depth (m), duration (min), total mean speed $\left(\mathrm{m} \mathrm{s}^{-1}\right)$, descent speed, ascent speed, descent rate (vertical distance $t^{-1}$ ), ascent rate, descent angle, ascent angle and the vertical and horizontal distances travelled during ascent and descent. Drift components were defined as periods when the turbine was stalled, thus giving a swim speed reading of $0 \mathrm{~m} \mathrm{~s}^{-1}$ (Fig. 1). Even though the animal was unlikely to be completely stationary relative to the surrounding water, stall speed effectively indicates no (or minimal) active propulsion. We further only used drift components that occurred at depths $>50 \mathrm{~m}$ to ensure minimal effects of residual air in the lungs affecting buoyancy (Biuw et al. 2003) and drag resistance because hydrostatic pressure reduces air volume (Miller et al. 2004) to negligible quantities below these depths (Biuw et al. 2003). The analysis was further restricted by only using drifting periods lasting longer than $3 \mathrm{~min}$ because a minimum of 6 consecutive records was needed to estimate drift rate accurately. Drift rate was calculated as the mean of the difference between each of the depths within each drift component divided by the sampling rate. There was often more than one drift component per dive, and all of these components were used in the analysis rather than calculating a mean drift rate per dive.

Speed sensor failures occurred occasionally and predominantly at the start of the trip when turbines were temporarily blocked by accumulated beach sand. We identified blockages by examining the total mean speed for all dives (not just the drift component); when these were zero, it was clear the turbine was blocked. A small number of these blockages occurred during the trip, presumably as a result of flotsam or large particulates becoming lodged in the turbine. There was no evidence to suggest progressive clogging and it appeared that the small number of blockages was cleared quickly. We omitted these periods of blockage from analysis.

Lipid content and relationship to drift rate. Total blubber mass at each capture was estimated using length, mass and blubber thickness measurements (details provided in Field et al. 2002). We surveyed the study area daily to determine arrival and departure dates, and seals were captured as close to these dates as possible. All body composition measurements were corrected for any small discrepancies between arrival/departure date and capture date assuming a constant rate of mass and blubber loss during the haulout period. Two mass loss equations were derived, one for the moulting season (which was also used for the pre-parturition period) and the other for mass loss during lactation:

$\mathrm{M}_{\mathrm{ML}}$ (moulting mass loss) = mean $\left[\left(\mathrm{M}_{\mathrm{M} 1}-\mathrm{M}_{\mathrm{M} 2}\right)\left(\mathrm{d}_{2}-\mathrm{d}_{1}\right)^{-1}\right]$ $\mathrm{M}_{\mathrm{BL}}$ (breeding mass loss) = mean $\left[\left(\mathrm{M}_{\mathrm{B} 1}-\mathrm{M}_{\mathrm{B} 2}\right)\left(\mathrm{d}_{2}-\mathrm{d}_{1}\right)^{-1}\right]$ where $\mathrm{M}_{\mathrm{M} 1}=$ mass at first capture (start of moult), $\mathrm{M}_{\mathrm{M} 2}=$ mass at second capture (end of moult), $\mathrm{d}_{1}=$ first capture date, $\mathrm{d}_{2}=$ second capture date, $\mathrm{M}_{\mathrm{B} 1}=$ mass at first capture (start of breeding) and $\mathrm{M}_{\mathrm{B} 2}=$ mass at second capture (end of breeding). We then used these equations to derive the arrival mass $\left(\mathrm{M}_{\mathrm{A}}\right)$ and departure mass $\left(\mathrm{M}_{\mathrm{D}}\right)$ in the moulting season as:

$$
\begin{aligned}
& M_{A}=M_{M 1}+\left[M_{M 1} \times\left(d_{1}-d_{H}\right) \times M_{M L}\right] \\
& M_{D}=M_{M 2}-\left[M_{M 2} \times\left(d_{3}-d_{2}\right) \times M_{M L}\right]
\end{aligned}
$$

where $d_{H}=$ haul-out date and $d_{3}=$ departure date. To derive $\mathrm{M}_{\mathrm{A}}$ in the breeding season, we first calculated the mass lost between $d_{1}$ and the parturition date $\left(d_{P}\right)$ :

$$
\left.\mathrm{M}_{\mathrm{P}} \text { (parturition mass }\right)=\mathrm{M}_{\mathrm{B} 1}+\left[\mathrm{M}_{\mathrm{B} 1} \times\left(\mathrm{d}_{1}-\mathrm{d}_{\mathrm{P}}\right) \times \mathrm{M}_{\mathrm{BL}}\right]
$$

followed by an estimate of mass loss for the period between parturition and haul out, including the mass of the female's pup:

$$
\mathrm{M}_{\mathrm{A}}=\mathrm{M}_{\mathrm{P}}+\left[\mathrm{M}_{\mathrm{P}} \times\left(\mathrm{d}_{\mathrm{P}}-\mathrm{d}_{\mathrm{H}}\right) \times \mathrm{M}_{\mathrm{ML}}\right]+\text { pup mass }
$$

Departure mass in the breeding season was calculated as:

$$
\mathrm{M}_{\mathrm{D}}=\mathrm{M}_{\mathrm{B} 2}-\left[\mathrm{M}_{\mathrm{B} 2} \times\left(\mathrm{d}_{3}-\mathrm{d}_{2}\right) \times \mathrm{M}_{\mathrm{BL}}\right]
$$

We used a different equation for the period between haul out and parturition (gestation) compared to the period between parturition and capture (lactation) because lactation in mammals is more energetically expensive than gestation (Gittleman \& Thomson 1988). 


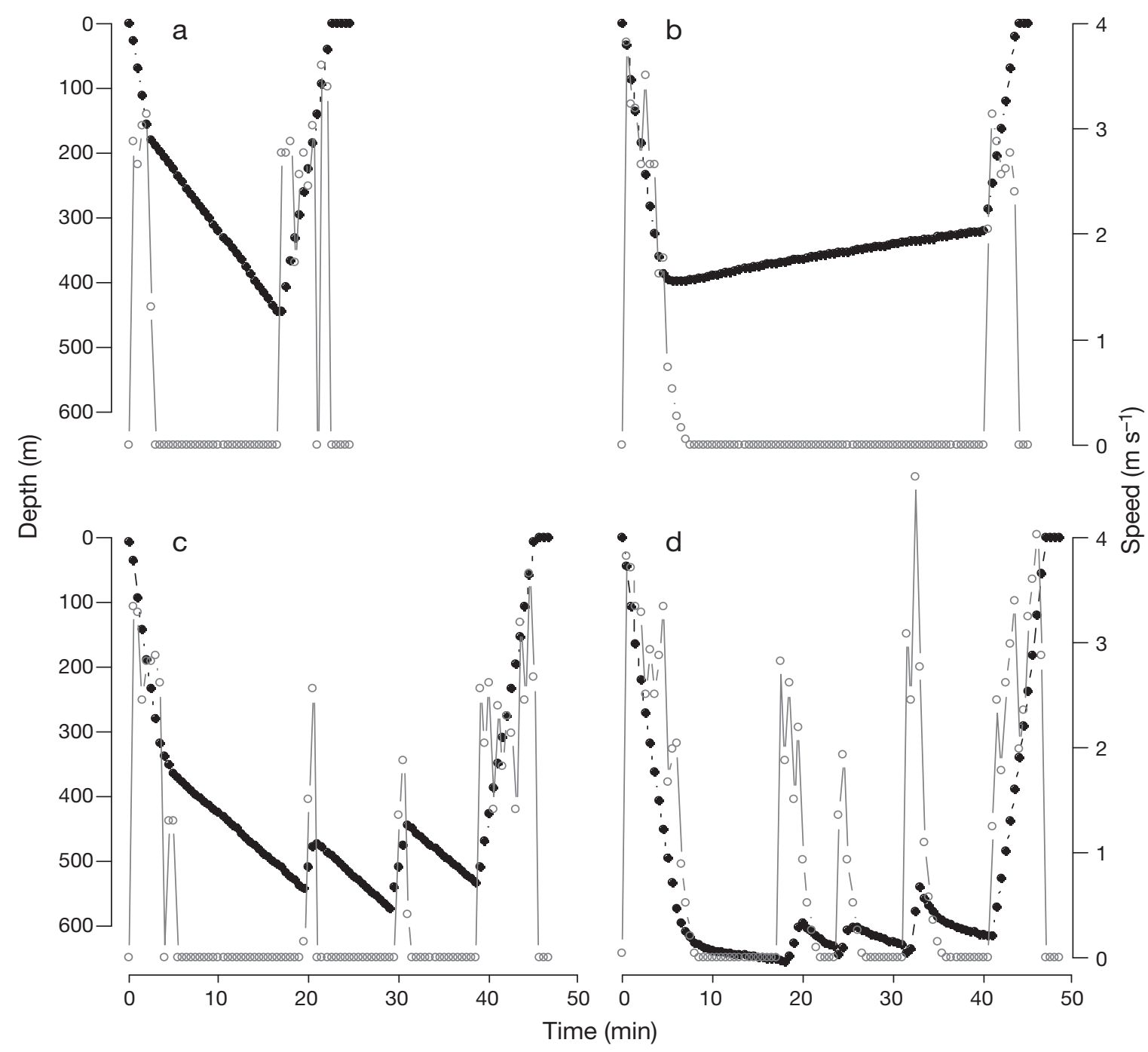

Fig. 1. Mirounga leonina. Examples of southern elephant seal dives with drifting components. $\mathrm{O}, \mathrm{speed}\left(\mathrm{m} \mathrm{s}^{-1}\right) ; \bullet$ (a) Drift dive identified from the beginning of a post-moult foraging trip when the seal was negatively buoyant during the drift phase, clearly identifiable by the measurement of zero swim speed during the passive drift component. Dive depth and swim velocity were recorded every $30 \mathrm{~s}$. (b) Drift dive identified from late in the post-moult foraging trip when the seal was positively buoyant during the drift phase. (c) A dive with multiple drift phases. (d) A putative foraging dive with drift components. Note: $0 \mathrm{~m} \mathrm{~s}^{-1}$ on the graph denotes any speed $\leq$ the stall speed of the instrument

Explaining variation in body composition. To explain variation in the log of body lipid content during the initial and final stages in each foraging trip, we constructed a suite of general linear models (GLMs) with a Gaussian distribution and an identity link using the log of percentage body lipid content (as estimated from onshore measurements) as the response variable, and drift rate (the drift rate of the first and last dive at the beginning and end of each foraging trip), descent rate, descent angle and seal length as potential correlates. We selected the first and last drift dive of the trip because the buoyancy and thus body composition inferred at these stages will be most indicative of the seals' actual body composition at arrival and depar- ture. Models were compared and ranked according to Akaike's Information Criterion corrected for small sample size $\left(\mathrm{AIC}_{\mathrm{C}}\right)$ (Burnham \& Anderson 2002), and predictions were made using information-theoretic model averaging (Burnham \& Anderson 2002).

Predicting body composition changes. Due to the large number of data and high variation within a day, we fitted a median smoothing spline to the data. We applied a constrained quadratic regression B-spline from the COBS library in the $R$ Package (R Development Core Team 2007) to the pattern of change in the relative body lipid content (derived from the model) over the foraging trip. The spline was constrained in that it fitted the median estimation of the response given the covari- 
ate. In this case the response was lipid content as predicted from the above models and the covariate was calendar date. The function's roughness was controlled by the number of internal knots rather than a smoothing parameter $\lambda$. The number of knots was chosen via the automated knot selection procedure in which COBS uses a stepwise knot deletion and addition process and then makes adaptive choices using an information criterion (He \& Ng 2006). Spline functions were fitted to the time series of relative body lipid content for each seal using all the available data (all drift components). These fitted values were then summarised for each day of the foraging trip. Hence, we could calculate the direction of change in the body lipid content between consecutive days. Based on the direction of change in the proportion of body lipid from day $i$ to $i+1$, we allocated a value of relative change in body lipid for each of the daily locations during a seal's time at sea.

\section{RESULTS}

Eight of the seals with VTDRs were not relocated after deployment, and instruments malfunctioned for another 11 deployments. This left 25 deployments for which we obtained data (18 PM; 7 PL). We obtained complete diving records (i.e. from entire foraging trips) from all but one of these (the VTDR ceased functioning 1 mo prior to returning to Macquarie Island). Based on arrival and departure dates, the mean foraging trip duration was $68.6 \pm 12.1 \mathrm{~d}$ and $234.4 \pm 6.0 \mathrm{~d}$ for the PL and PM trips, respectively.

\section{Drift diving behaviour}

A typical drift dive (Crocker et al. 1997, Biuw et al. 2003) consists of a period of relatively rapid descent followed by a passive drift phase of slow, constant descent (Fig. 1a) or ascent (Fig. 1b). This is then fol- lowed by a period of rapid ascent, and some of these may have more than one drifting component (Fig. 1c). However, swim speed data indicated that not all dives with drift components had these distinctive profiles. Rather, drift components were also found within putative foraging dives (Hindell et al. 1991b) during the downward (Fig. 1d) and upward 'wiggles' of the characteristic bottom phases of these dives.

There were some obvious differences between PM and PL for the parameters measured for drifting behaviour (Table 1). Most notably, dives with drift components comprised $5.53 \pm 4.58 \%$ of the total number of PL dives and $23.95 \pm 9.68 \%$ of all PM dives. During PM there was a large, general increase in drift rate (Fig. 2a,b \& Fig. A1, available in the online appendix at www.int-res.com/articles/suppl/m370p249_app.pdf) with drift rate increasing from $12.4 \pm 8.6 \mathrm{~d}$ after departure and reaching positive values at $84.5 \pm 27.9 \mathrm{~d}$. All individuals decreased drift rate from $40.4 \pm 24.6 \mathrm{~d}$ before the end of the PM trip (Fig. A1). There was a large range in the number of days spent in positive buoyancy (where drift rates were positive) (range $=2$ to $143 ; 68.5 \pm 54.0 \mathrm{~d}$ ). All PL records demonstrated an increasing trend in drift rate while at sea after initially declining for the first $7.9 \pm 7.0 \mathrm{~d}$ after departure (Fig. 3c,d, \& Fig. A2 in the online appendix). No individuals achieved positive drift rates during PL. Four of the 7 PL seals showed a small decrease in drift rate in the final 6 to $8 \mathrm{~d}$ of the trip, while the other 3 seals maintained their drift rate or increased it until the trip's end (Fig. A2). Descending drifts comprised 59\% of all drifting dives during PM and 100\% during PL.

\section{Predicting lipid content}

We measured the onshore body composition of seals on 47 occasions, either only at departure from $(n=4)$, or only return to Macquarie Island $(\mathrm{n}=3)$ or both $(\mathrm{n}=$ 40) at (1) parturition or the following day, (2) an aver-

Table 1. Mirounga leonina. Aspects of drifting dive behaviour in southern elephant seals. PM = post-moult trip (February to September) 2002, 2004 and 2005; PL = post-lactation trip (October 2004 to January 2005). Data are means and SD for whole foraging trips. Starting depth = the mean starting depth of the drifting component in a drifting dive (1st component if there was more than one), drifting dive duration = the mean duration of drifting dives, drifting duration = the mean duration of the drifting component of drifting dives, dives bout ${ }^{-1}=$ the mean no. of drifting dives that occurred in a bout of drifting dives, bouts $\mathrm{d}^{-1}=$ the mean no. of bouts of drifting dives that occurred per day, \% with $>1$ components $=$ the mean no. of drifting dives that had more than 1 drifting component, \% dives in bouts = the mean percentage of drifting dives that occurred in bouts compared to those that occurred singly

\begin{tabular}{|lccccccccc|}
\hline $\begin{array}{c}\text { \% dives } \\
\text { with drift }\end{array}$ & $\begin{array}{c}\text { Starting } \\
\text { depth (m) }\end{array}$ & $\begin{array}{c}\text { Maximum } \\
\text { depth (m) }\end{array}$ & $\begin{array}{c}\text { Drifting dive } \\
\text { duration (min) }\end{array}$ & $\begin{array}{c}\text { Drifting } \\
\text { duration (min) }\end{array}$ & $\begin{array}{c}\text { Dives } \\
\text { bout }^{-1}\end{array}$ & $\begin{array}{c}\text { Bouts } \\
\mathrm{d}^{-1}\end{array}$ & $\begin{array}{c}\% \text { with }>1 \\
\text { components }\end{array}$ & $\begin{array}{c}\% \text { dives in } \\
\text { bouts }\end{array}$ \\
\hline PM & $24.0 \pm 9.7$ & $332.7 \pm 56.2$ & $431.7 \pm 51.0$ & $37.2 \pm 3.5$ & $11.8 \pm 1.7$ & $5.4 \pm 5.6$ & $2.3 \pm 1.4$ & $32.2 \pm 9.8$ & $88.9 \pm 4.6$ \\
PL & $5.5 \pm 4.58$ & $280.2 \pm 41.1$ & $422.6 \pm 54.5$ & $24.1 \pm 4.5$ & $7.5 \pm 1.6$ & $3.3 \pm 1.6$ & $1.3 \pm 0.6$ & $4.1 \pm 3.1$ & $77.0 \pm 11.6$ \\
\hline
\end{tabular}


age of $2.9 \pm 2.3 \mathrm{~d}$ prior to departure at the end of lactation, (3) an average of $0.8 \pm 1.4 \mathrm{~d}$ after arrival at moult and (4) an average of $2.7 \pm 3.1 \mathrm{~d}$ prior to departure at the end of the moult. The first and last drift dives in each seal's record was within $2.31 \pm 2.43 \mathrm{~d}$ of arrival and departure, respectively. Body composition values for the start and end of each foraging trip are summarized in Table 2. Over $90 \%$ of the deviance (\%DE) in the proportion of body lipid was explained by a GLM including drift rate, descent rate and seal length (Table 3). Other variables such as descent speed, mean total speed and drift duration only contributed an additional $<1 \% \mathrm{DE}$ and so were not included in the final predictive model. We also initially constructed general linear mixed-effects models (GLMM) with individual coded as a random factor because each individual provides data from the both the beginning and end of the foraging trip (repeated measure). However GLMMs did not modify the model ranking and the \%DE, so we used the GLM results exclusively. Most variation was explained by drift rate $(77 \%)$; thus, fatter seals were more buoyant (slower drift rate) than leaner seals (Fig. 3). Another $12 \%$ was explained by seal length (Table 3). Comparing the modelled arrival fat with the measured fat content gave a mean percentage error for the PM and PL trips combined of $5.49 \pm 3.79 \%$ or a mean difference of $1.25 \pm 0.90 \%$ lipid (Table A1 in the online appendix).

\section{Temporal resolution}

The mean number of spline knots (where a detectable change in relative body lipid content occurred)
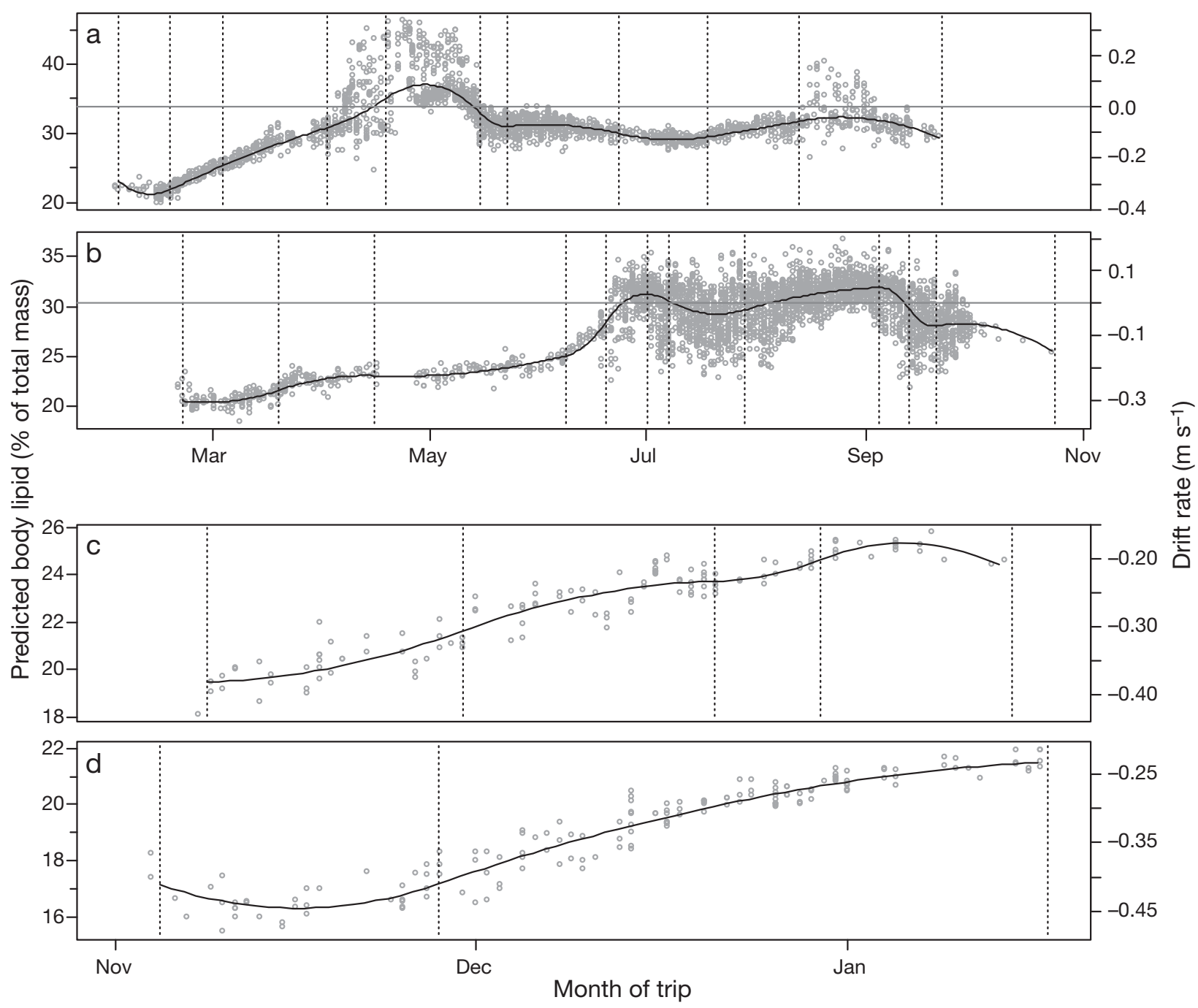

Fig. 2. Mirounga leonina. Predicted body lipid content from the GLM plotted against time for 2 seals from the post-moult $(\mathrm{PM}, \mathrm{a}, \mathrm{b})$ and 2 seals from the post-lactation ( $\mathrm{PL}, \mathrm{c}, \mathrm{d})$ foraging trips. Drift rate is plotted on the right hand $y$-axis. Spline fit (black line) and spline knot placements (vertical dotted lines) are shown 
Table 2. Mirounga leonina. Change in body mass, estimated lipid mass and proportion of lipid by mass for each of the 2 annual haul-out periods for adult female southern elephant seals

\begin{tabular}{|lcccc|}
\hline & $\begin{array}{c}\text { N } \\
\text { (no. of ind. } \\
\text { measured) }\end{array}$ & $\begin{array}{c}\text { Mass } \\
\text { (mean } \pm \mathrm{SD} \text { ) }\end{array}$ & $\begin{array}{c}\text { Estimated lipid } \\
\text { mass }(\mathrm{kg})\end{array}$ & $\begin{array}{c}\text { Mean \% lipid } \\
\text { by mass }\end{array}$ \\
\hline $\begin{array}{l}\text { Post-lactation trip } \\
\text { End of breeding }\end{array}$ & 7 & $362.9 \pm 75.1$ & $78.2 \pm 28.9$ & $21.02 \pm 3.70$ \\
Start of moult & 5 & $465.2 \pm 49.1$ & $106.1 \pm 16.4$ & $22.76 \pm 2.00$ \\
Post-moult trip & & & & \\
$\begin{array}{l}\text { End of moult } \\
\text { Start of breeding }\end{array}$ & 18 & $355.5 \pm 36.8$ & $73.8 \pm 13.0$ & $20.71 \pm 2.13$ \\
\hline
\end{tabular}

selected for the relationship between predicted body lipid and time using the information criterion was $11.0 \pm$ 1.9 for PM and $3.6 \pm 1.3$ for PL (Fig. 2 and Figs. A1 \& A2). The mean time between knots was $23.0 \pm 4.9 \mathrm{~d}$ (mean min. $=7.8 \pm 2.5 \mathrm{~d})$ for PM and $30.0 \pm$ $14.1 \mathrm{~d}$ (mean $\min$. $=25.2 \pm 16.6 \mathrm{~d}$ ) for PL. This value indicates the minimum number of days over which a change in predicted lipid content can be detected.

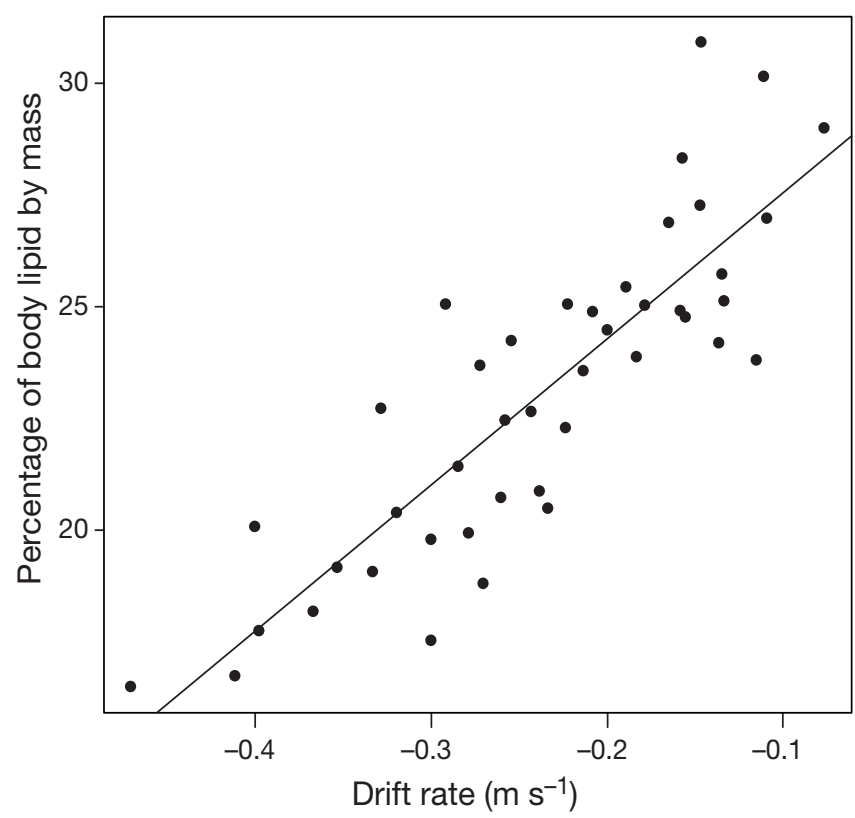

Fig. 3. Mirounga leonina. Linear relationship between drift rate (first and last drift dive of foraging trip) and the corresponding proportion of total body lipid by mass (departure and/or arrival) calculated for $\mathrm{n}=26$ female southern elephant seals. Least-squares linear line of best fit is shown $\left(\mathrm{R}^{2}=0.72\right)$

Table 3. Mirounga leonina. Ranked generalized linear models of proportion body fat explained by drift rate, descent rate and body length ( $\mathrm{n}=37$ seals). Shown are the percent deviance explained in the response (\%DE), change in Akaike's Information Criterion corrected for small samples relative to the top-ranked model $\left(\Delta \mathrm{AIC}_{\mathrm{c}}\right)$ and $\mathrm{AIC}_{\mathrm{c}}$ model weights $\left(w_{i}\right)$

\begin{tabular}{|lccc|}
\hline Model & $\% \mathrm{DE}$ & $\Delta \mathrm{AIC}_{\mathrm{c}}$ & $w_{i}$ \\
\hline $\begin{array}{l}\text { Drift rate + descent } \\
\text { rate + length }\end{array}$ & 90.28 & 0.00 & 0.74 \\
$\begin{array}{l}\text { Drift rate + length } \\
\text { Drift rate }\end{array}$ & 88.73 & 2.07 & 0.26 \\
$\begin{array}{l}\text { Drift rate + descent angle } \\
\text { Drift + descent rate }\end{array}$ & 76.61 & 23.58 & $<0.01$ \\
& 77.85 & 24.38 & $<0.01$ \\
\end{tabular}

\section{Temporal and spatial patterns in relative body lipid changes}

Drift rate decreases at the start of PL corresponded to a small loss of $0.3 \pm 0.3 \%$ of their initial proportional body lipid. For 4 seals showing drift rate decreases towards the end of the PL trip, this period corresponded to a loss of $0.9 \pm 0.2 \%$ of their proportional body lipid. The remaining 3 seals maintained their relative body lipid or gained up until the end of their trips. The maximum percentage of body lipid reached by PL seals was $24.1 \pm 2.0 \%$ (Table A1). Drift rate decreases at the start of PM corresponded to a loss of $1.1 \pm 1.2 \%$ of initial proportional body lipid. Maximum relative lipid content was attained $129.0 \pm 50.4 \mathrm{~d}$ into the PM trip (corresponding to a max. \% body lipid $=32.7 \pm 3.2 \%$; Table A1). Drift rate decreases at the end of the PM trip corresponded to a $3.8 \pm 3.2 \%$ loss of proportional body lipid.

Losses in relative body lipid during PM at the start and end of the foraging trips often corresponded to part or all of the inward and outward travelling phases away from and to Macquarie Island (Fig. 4). The duration of time in which relative lipid was lost was often shorter than the entire outward travelling phase, suggesting successful foraging during part of these travelling phases. Lipid loss at the end of a trip almost always corresponded to the return to Macquarie Island. In PM, most time spent was in the north of the Ross Sea in the pack-ice zone, off the coast of east Antarctica and below the Antarctic Polar Front (APF) west of Macquarie Island (Fig. 5). The highest number of days where seals increased their body lipid corresponded to these same regions (Fig. 5). In PL, most time spent was within the major Antarctic Circumpolar Current (ACC) fronts (more specifically in the Polar Frontal zone and Sub-Antarctic zone, east and west of Macquarie Island). There was also a reasonable amount of time spent just below the Southern Boundary of the ACC, ca. $160^{\circ} \mathrm{S}$ latitude (Fig. 5). Again, the highest number of days where seals increased their body lipid corresponded to these same regions, and a linear regression 

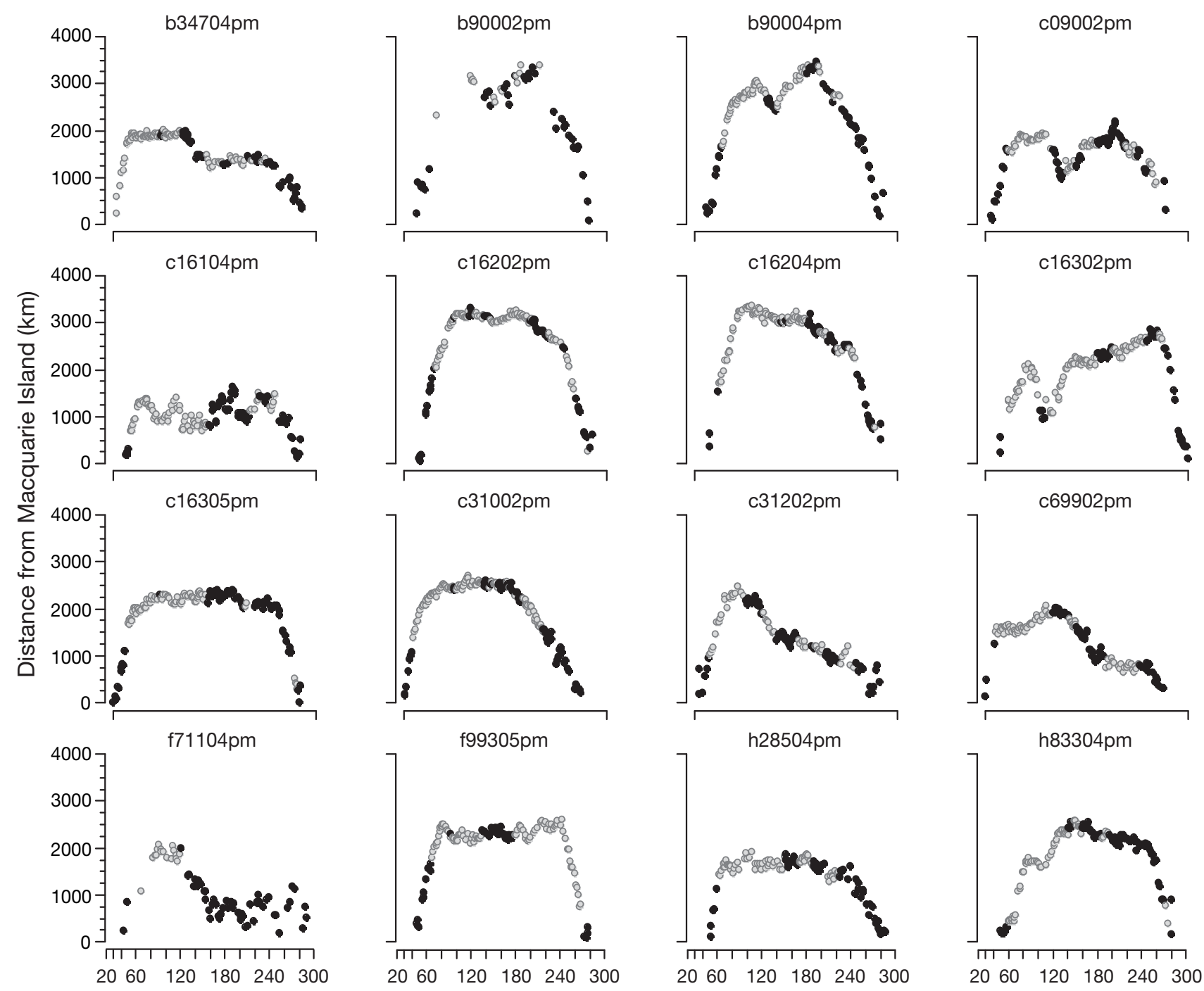

Day of the year

Fig. 4. Mirounga leonina. Relationship between distance from Macquarie Island and relative body lipid content for post-moult seals. O: gaining relative body lipid; $\bullet$ : loss of relative body lipid

showed a positive relationship between time spent in $100 \times 100 \mathrm{~km}$ grid cells and the number of days gaining condition in these same grid cells $\left(\mathrm{PM}_{i} \mathrm{R}^{2}=0.70, \mathrm{p}<\right.$ 0.001 and $\left.\mathrm{PL}_{i} \mathrm{R}^{2}=0.62, \mathrm{p}<0.001\right)$.

\section{DISCUSSION}

Our analysis is the first to allocate spatial and temporal estimates of relative body composition derived from drifting behaviour in a marine predator, thus identifying where and when prey acquisition occurs in the Southern Ocean. Even though regular drift diving in pinnipeds has only been observed in elephant seals (Hindell et al. 1991b, Crocker et al. 1997, Biuw et al. 2003) and New Zealand fur seals (Page et al. 2005), our observation of drifting during dives not normally considered as 'drift' dives (Fig. 1d) highlights the utility of using speed data to identify periods of drifting for any diving vertebrate which ceases active swimming during part of its dive. Most seals and some cetaceans investigated to date use a variety of locomotor activity including continuous stroking, burst and glide and prolonged gliding (Williams et al. 2000, Nowacek et al. 2001, Sato et al. 2003, Miller et al. 2004, Watanabe et al. 2006), and indeed Miller et al. (2004) used 3-axis accelerometers to measure periods of gliding in sperm whales and fit a model of drag and buoyancy forces acting on them. Such technology expands the method of monitoring changes in relative body composition using changes in buoyancy to of a range of marine vertebrates. 

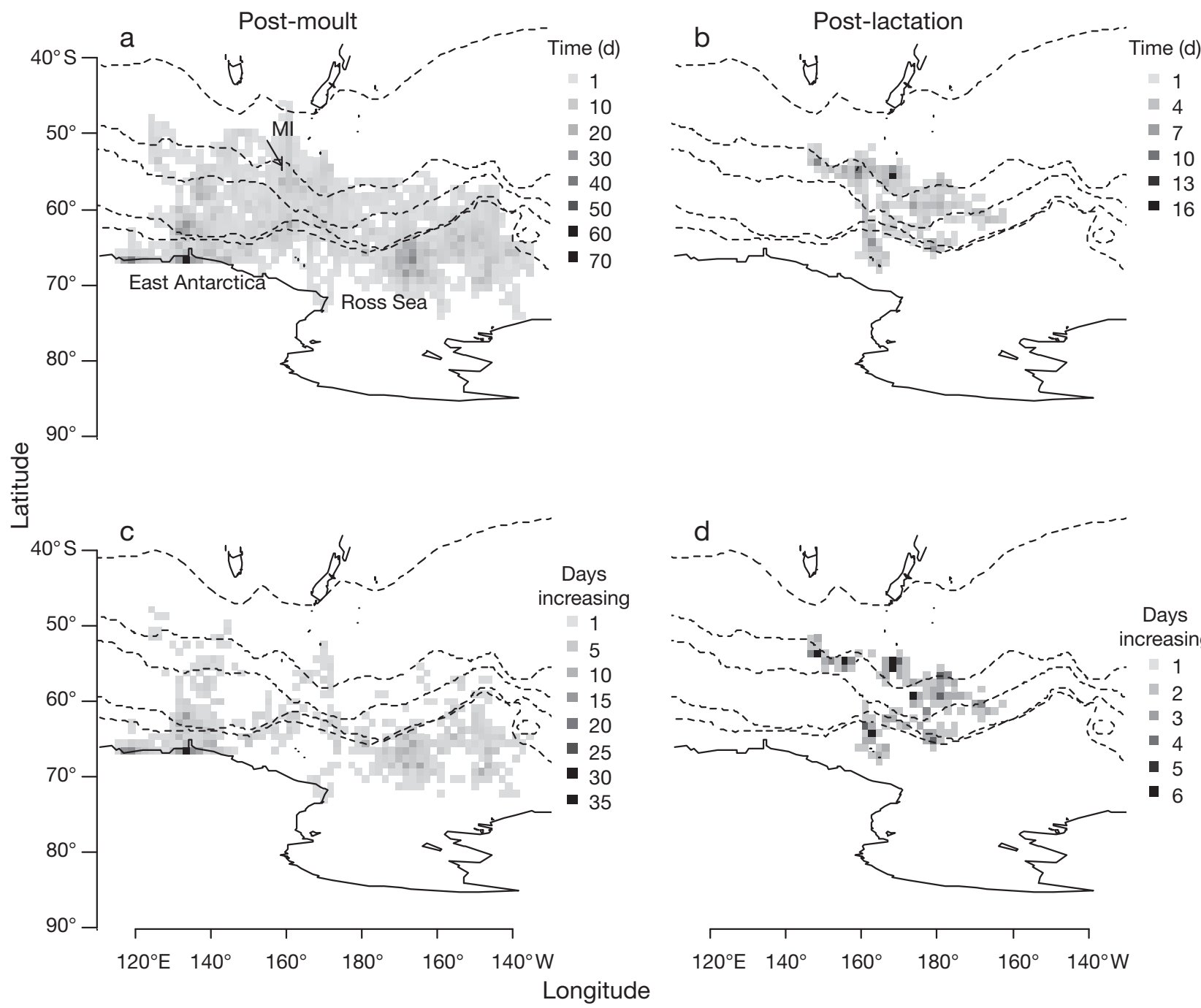

Fig. 5. Mirounga leonina. (a,b) Time spent within $100 \times 100 \mathrm{~km}$ grid cells for (a) post-moult and (b) post-lactation seals, and (c,d) number of days spent increasing relative body lipid (thus representing areas where seals increased their relative body lipid) in those same grid cells during both periods. MI = Macquarie Island. Dashed lines show major Antarctic circumpolar current fronts (from north to south): Subtropical Front, Sub-Antarctic Front, Southern Antarctic Circumpolar Current Front, Antarctic Polar Front and Southern Boundary of Antarctic Circumpolar Current Front

The application of relatively simple behavioural and morphological measurements taken from archival tags and onshore captures can reveal important information regarding the timing and location of relative foraging success in wide-ranging diving predators. Although more direct measures of foraging success have been applied to other marine mammals (e.g. Austin et al. 2006) and seabirds (e.g. Simeone \& Wilson 2003, Weimerskirch et al. 2005), the approach we describe is the only one currently available that provides a measure over broad spatial and temporal scales. Spatial allocation of relative foraging success determined using drifting dives incorporates more than a simple index of prey acquisition; it also combines nutrient assimilation and concomitant changes in total body com- position (density). As such, it is a potentially truer expression of foraging success because it summarises information on hunting success through to lipid storage.

\section{Limitations of method}

Drifting rates do not necessarily reflect absolute changes in lipid composition even though they can provide good estimates of relative lipid content (Biuw et al. 2003). The way in which energy use and storage is regulated depends largely on an individual's current physiological state and energy deficit; therefore, changes in relative body composition depend on an individual's foraging success and on its current body 
state and energy requirements. This is particularly important during periods ashore for breeding and moulting when seals expend energy and material stored over the course of the foraging trip (Fedak et al. 1994). Although lipid is the primary fuel for these periods ashore, protein is also lost (Fedak et al. 1994) and must be recovered. Thus, the drift rate decreases we note at the start of female foraging trips may be at least partially associated with lean tissue recovery rather than lipid depletion alone. We acknowledge this limitation of interpreting buoyancy decreases, particularly early in a trip and at the end of the PM trip, when protein deposition occurs from the presence of the almost full-term foetus. However the converse is not so ambiguous; buoyancy increases are due mainly to lipid assimilation rather than protein depletion, as there is no physiological reason that a seal would deplete protein stores whilst foraging. This assumption is supported by the positive relationship between lipid assimilation (as inferred from drift rate) and time spent in foraging areas.

The proportion of dives containing a drift phase during PL was similar to that described for northern elephant seals Mirounga angustirostris by Crocker et al. (1997); however, we determined that there were considerably more dives with drift components in southern elephant seals than northern elephant seals during the PM foraging trip ( $24 \%$ for $M$. leonina versus $7 \%$ for $M$. angustirostris). Le Boeuf et al. (2000) found that the proportion of drift dives doubled once $M$. angustirostris attained foraging areas; we found that $M$. leonina quadrupled this proportion after the travelling phase (Fig. 4). This higher value is most certainly due mainly to the different approach used here to identify drift components. Swim speed data highlighted many more drift components in several dive types (i.e. not just classic drift dives) which would not have been detected by examining the shape of the putative drift segment used by Crocker et al. (1997) and Le Boeuf et al. (2000). We discovered drifting behaviour on both the ascent and descent of the bottom 'wiggles' of putative foraging dives depending on whether a seal was positively or negatively buoyant. We contend therefore that drifting behaviour is more common than previously thought, highlighting the importance of collecting speed or acceleration data to detect drifting. This suggests that drifting may have multiple functions in addition to the rest or food/lactate processing role previously proposed by Crocker et al. (1997). Other functions may include energy conservation in long foraging dives or even a part of hunting tactics (e.g. prey-stalking behaviour).

Changes in buoyancy generally correlate well with changes in body composition in phocids (Hindell et al. 1991a, Crocker et al. 1997, Webb et al. 1998, Beck et al. 2000, Irvine et al. 2000, Biuw et al. 2003). The unex- plained variation in our GLM may derive, in part, from changes in drift rate associated with fine-scale temporal variation in body density, drag and body angle during ascent/descent (Biuw et al. 2003). Indeed, the addition of seal length (an index of body size independent of short-term fluctuation in mass) improved the fit by $12 \%$, which can be explained by the increased drag of longer bodies with greater surface area (Vogel 1981, Schmidt-Nielsen 1997). Of the various sources of error affecting the estimation of buoyancy and body composition, drag is certainly the most important; indeed, variation in drag force can leading to errors $\geq 10 \%$ (Biuw et al. 2003). Drag force is also expected to vary in response to postural changes during drifting (Biuw et al. 2003), although our predictions of body lipid content based on drift rate and body length were still within $1.25 \pm 0.90 \%$ of estimated values. Vertical currents may also affect drift rates, but few data exist to predict the magnitude of this potential source of error.

\section{Temporal resolution of relative body lipid changes}

Small changes in body composition and behaviour when seals are close to neutral buoyancy produce large changes in drift rate (Biuw et al. 2003), an observation that may explain much of the variability within a dive and between dives in PM trips (Figs. 3 \& A1). The smoothing spline fits demonstrated that there were fewer fluctuation points in the PL trips and that there was a detectable change in body lipid content every $23 \mathrm{~d}$ during the $\mathrm{PM}$, and every $30 \mathrm{~d}$ during $\mathrm{PL}$, trips. The number of days between each fluctuation point was variable, particularly during PM (min. time over which a change was detectable $=6 \mathrm{~d}$ ), a resolution supported from previous analyses (Biuw et al. 2003). Such a resolution is to be expected given that daily lipid gain is probably small in proportion to the large lipid store carried by the seal (Biuw et al. 2003).

\section{Temporal pattern in relative body lipid changes}

Greater relative lipid loss during the outgoing (migration) phase of the PM trip may be explained by the greater distance required to reach foraging areas at that time (Bradshaw et al. 2003), or it is possibly related to protein deposition as discussed earlier. PM seals also lost more relative lipid at the end of the foraging trip $(4 \pm 3 \%)$ compared to PL individuals $(0.9 \pm$ $0.2 \%$ ). The magnitude of this difference is possibly related to protein deposition resulting from the presence of a rapidly growing foetus (which is comprised mainly of non-lipid tissue, Hindell et al. 1994) in the latter stages of pregnancy (Crocker et al. 1997). We 
accounted for the $2.0 \pm 0.3 \%$ adjustment to a mother's lipid content at arrival based on her pup's lean mass, indicating that body density changes near the end of the PM trip are not explained by lipid loss alone; it also incorporates body composition changes due to higher proportional lean tissue associated with foetal growth. Other determinants of reduced relative lipid composition include (1) recovery of lean tissue losses from breeding, (2) the allocation of relatively more energy to the growing foetus, (3) rapid transit to and from breeding and moulting sites taking precedence over feeding (Crocker et al. 1997, Biuw et al. 2003) and (4) transit occurring in relatively resource-poor waters. Given that the seals examined here were mature adults that demonstrate limited somatic growth, we do not consider developmental growth of lean body mass to be a large determinant of drift rate changes.

\section{Spatial pattern in foraging success}

During the PM trip, few increases in body lipid content occurred within the major oceanic frontal systems characterizing the region. Instead, seals travelled directly to their principal foraging areas which were mostly below the Southern Boundary of the ACC, in the sea-ice zone, including the northern part of the Ross Sea and along the continental shelf and shelf break of East Antarctica (cf. Biuw et al. 2007). In contrast, PL foraging seals spent the majority of their time and increased body lipid most rapidly within these frontal zones (in the Polar Frontal and Sub-Antarctic zones). These results are consistent with past studies that have found associations of PL seals with the major frontal systems of the region (Hindell et al. 1991b, Bradshaw et al. 2003, 2004, Bailleul et al. 2007). It is thought that higher temperature gradients within frontal systems are associated with higher relative productivity than surrounding areas (Rintoul et al. 2001). Bailleul et al. (2007) found that PM southern elephant seals originating from îles Kerguelen (south Indian Ocean) foraged successfully along the Polar Front where surface waters tended to be warmer. Likewise, PM seals originating from Macquarie Island foraging within the Ross Sea tended to favour warmer waters near sharp discontinuities in temperature and salinity (Biuw et al. 2007).

We suggest that PL seals cannot travel as far south as PM seals due to time constraints; the PL trip lasts ca. $73 \mathrm{~d}$ relative to the average $240 \mathrm{~d}$ of the PM trip (Hindell \& Burton 1988). The function of each trip also differs; PM foraging serves to accrue energy for pup growth and lactation and requires about twice as much energy as the moulting process (Boyd et al. 1993). Prey differences associated with particular regions may have also contributed to differences in relative body composition. Fish prey, including larger species within the Notothenidae and Moridae, are an important component of seal diets when they travel to their more southerly ranges; this contrasts with the more squiddominated diets of seals foraging within the more northerly sub-Antarctic waters (Bradshaw et al. 2003).

There was good agreement between the spatial summaries of time spent and lipid gain, supporting the use of drift rate data for inferring foraging success. The real strength of drift rate data is that it can be expressed as both a temporal (unlike time-spent spatial summaries) and spatial series, enabling foraging to be examined along a movement path. Temporal and spatial allocation of relative body composition estimates derived from drifting behaviour in a wide-ranging marine predator provides a clearer understanding of elephant seal prey consumption patterns. In addition, it highlights another approach to quantify energy assimilation patterns for other species. With the accumulation of similar data from other species exploiting different prey communities, the use of passive vertical drifting rates can provide important additional information to derive more realistic models to estimate energy flow and trophic structure of the Southern Ocean ecosystem.

Acknowledgements. This research was funded by Australian Research Council, Natural Sciences and Engineering Research Council of Canada, Sea World Research and Rescue Foundation Inc. and Australian Antarctic Science grants, with additional support from P. Rowsthorn and the University of Tasmania. M. T. was supported by an Australian Postgraduate Award. We thank H. Achurch, C. Brown, D. Hamer, C. Holland, A. Irvine, R. Trebilco, S. Wall and S. Weeks for assistance with the field work and M. Biuw for comments on analyses.

\section{LITERATURE CITED}

Austin D, Bowen BW, McMillan JI, Boness DJ (2006) Stomach temperature telemetry reveals temporal patterns of foraging success in a free-ranging marine mammal. J Anim Ecol 75:408-420

Baechler J, Beck CA, Bowen WD (2002) Dive shapes reveal temporal changes in the foraging behaviour of different age and sex classes of harbour seals (Phoca vitulina). Can J Zool 80:1569-1577

> Bailleul F, Charrassin JB, Monestiez P, Roquet F, Biuw M, Guinet C (2007) Successful foraging zones of southern elephant seals from the Kerguelen Islands in relation to oceanographic conditions. Philos Trans R Soc Lond B Biol Sci 362:2169-2181

Bascompte J, Melian CJ, Sala E (2005) Interaction strength combinations and the overfishing of a marine food web. Proc Natl Acad Sci USA 102:5443-5447

Beck CA, Bowen WD, Iverson SJ (2000) Seasonal changes in buoyancy and diving behaviour of adult grey seals. J Exp Biol 203:2323-2330 
Bekkby T, Bjorge A (1998) Variation in stomach temperature as indicator of meal size in harbor seals, Phoca vitulina. Mar Mamm Sci 14:627-637

Biuw M, McConnell BJ, Bradshaw CJA, Burton HR, Fedak MA (2003) Blubber and buoyancy: monitoring the body condition of free-ranging seals using simple dive characteristics. J Exp Biol 206:3405-3423

Biuw M, Boehme L, Guinet C, Hindell MA and others (2007) Variations in behaviour and condition of a Southern Ocean top predator in relation to in-situ oceanographic conditions. Proc Natl Acad Sci USA 104:13705-13710

Bost CA, Georges JY, Guinet C, Cherel Y and others (1997) Foraging habitat and food intake of satellite-tracked king penguins during the summer at Crozet Archipelago. Mar Ecol Prog Ser 150:21-33

Bost CA, Handrich Y, Butler PJ, Fahlman A, Halsey LG, Woakes AJ, Ropert-Coudert Y (2007) Changes in dive profiles as an indicator of feeding success in king and Adelie penguins. Deep-Sea Res II 54: 248-255

Bowen WD, Tully D, Boness DJ, Bulheier BM, Marshall GJ (2002) Prey-dependent foraging tactics and prey profitability in a marine mammal. Mar Ecol Prog Ser 244: 235-245

Boyd I, Arnbom T, Fedak M (1993) Water flux, body composition, and metabolic rate during molt in female southern elephant seals (Mirounga leonina). Physiol Zool 66: 43-60

Bradshaw CJA, Hindell MA, Best NJ, Phillips KL, Wilson G, Nichols PD (2003) You are what you eat: describing the foraging ecology of southern elephant seals (Mirounga leonina) using blubber fatty acids. Proc R Soc Lond B Biol Sci 270:1283-1292

Bradshaw CJA, Hindell MA, Sumner MD, Michael KJ (2004) Loyalty pays: potential life-history consequences of fidelity to marine foraging regions by southern elephant seals. Anim Behav 68:1349-1360

Burnham KP, Anderson DR (2002) Model selection and multimodel inference: a practical information-theoretic approach. Springer-Verlag, New York

Charrassin JB, Kato A, Handrich Y, Sato K and others (2001) Feeding behaviour of free-ranging penguins determined by oesophageal temperature. Proc R Soc Lond B Biol Sci 268:151-157

Constable AJ, de la Mare WK, Agnew DJ, Everson I, Miller D (2000) Managing fisheries to conserve the Antarctic marine ecosystem: practical implementation of the Convention on the Conservation of Antarctic Marine Living Resources (CCAMLR). ICES J Mar Sci 57:778-791

Crocker DE, Le Boeuf BJ, Costa DP (1997) Drift diving in female northern elephant seals: implications for food processing. Can J Zool 75:27-39

Davis RW, Fuiman LA, Williams TM, Collier SO and others (1999) Hunting behavior of a marine mammal beneath the Antarctic fast ice. Science 283:993-996

Fauchald P, Tveraa T (2006) Hierarchical patch dynamics and animal movement pattern. Oecologia 149:383-395

Fedak MA, Arnbom TA, McConnell BJ, Chambers C, Boyd IL, Harwood J, McCann TS (1994) Expenditure, investment, and acquisition of energy in southern elephant seals. In: Le Boeuf BJ, Laws RM (eds) Elephant seals: population ecology, behavior, and physiology. University of California Press, Berkeley, p 354-373

Field IC, Bradshaw CJA, McMahon CR, Harrington J, Burton HR (2002) Effects of age, size and condition of elephant seals (Mirounga leonina) on their intravenous anaesthesia with tiletamine and zolazepam. Vet Rec 151:235-240

Field IC, Bradshaw CJ, Burton HR, Hindell MA (2007) Differ- ential resource allocation strategies in juvenile elephant seals in the highly seasonal Southern Ocean. Mar Ecol Prog Ser 331:281-290

> Fletcher S, Le Boeuf BJ, Costa DP, Tyack PL, Blackwell SB (1996) Onboard acoustic recording from diving northern elephant seals. J Acoust Soc Am 100:2531-2539

Gittleman JL, Thomson SD (1988) Energy allocation in mammalian reproduction. Am Zool 28:863-875

Guinet C, Dubroca L, Lea MA, Goldsworthy S and others (2001) Spatial distribution of the foraging activity of Antarctic fur seal Arctocephalus gazella females in relation to oceanographic variables: a scale-dependent approach using geographic information systems. Mar Ecol Prog Ser 219:251-264

> Hassrick JL, Crocker DE, Zeno RL, Blackwell SB, Costa DP, Le Boeuf BJ (2007) Swimming speed and foraging strategies of northern elephant seals. Deep-Sea Res II 54:369-383

He X, Ng P (2006) COBS: Qualitatively constrained smoothing via linear programming. www.cba.nau.edu/pin-ng/ cobs.html

> Hindell MA, Burton HR (1988) Seasonal haul-out patterns of the southern elephant seal (Mirounga leonina L.) at Macquarie Island. J Mammal 69:81-88

Hindell MA, Slip DJ (1997) The importance of being fat: maternal expenditure in the southern elephant seal Mirounga leonina. In: Hindell M, Kemper C (eds) Marine mammal research in the Southern Hemisphere, Vol 1: status, ecology and medicine. Surrey Beatty and Sons, Chipping Norton, p 72-77

> Hindell MA, Burton HR, Slip DJ (1991a) Foraging areas of southern elephant seals, Mirounga leonina, as inferred from water temperature data. Aust J Mar Freshw Res 42: $115-128$

Hindell MA, Slip DJ, Burton HR (1991b) The diving behaviour of adult male and female southern elephant seals, Mirounga leonina (Pinnipedia: Phocidae). Aust J Zool 39: 595-619

Hindell MA, Bryden MM, Burton HR (1994) Early growth and milk composition in southern elephant seals (Mirounga leonina). Aust J Zool 42:723-732

> Hindell MA, Bradshaw CJA, Sumner MD, Michael KJ, Burton HR (2003) Dispersal of female southern elephant seals and their prey consumption during the austral summer: relevance to management and oceanographic zones. J Appl Ecol 40:703-715

> Hooker SK, Boyd IL, Jessop M (2002) Monitoring the preyfield of marine predators: combining digital imaging with datalogging tags. Mar Mamm Sci 18:680-697

Horsburgh JM, Morrice MG, Lea MA, Hindell MA (2008) Determining feeding events and prey encounter rates in a southern elephant seal: a method using swim speed and stomach temperature. Mar Mamm Sci 24:207-217

Irvine LG, Hindell MA, van den Hoff J, Burton HR (2000) The influence of body size on dive duration of underyearling southern elephant seals (Mirounga leonina). J Zool 251: 463-471

Le Boeuf BJ, Naito Y, Asaga T, Crocker D, Costa DP (1992) Swim speed in a female northern elephant seal: metabolic and foraging implications. Can J Zool 70:786-795

Le Boeuf BJ, Crocker DE, Costa DP, Blackwell SB, Webb PM, Houser DS (2000) Foraging ecology of northern elephant seals. Ecol Monogr 70:353-382

Lesage V, Hammill MO, Kovacs KM (1999) Functional classification of harbor seal (Phoca vitulina) dives using depth profiles, swimming velocity, and an index of foraging success. Can J Zool 77:74-87

Liebsch N, Wilson RP, Bornemann H, Adelung D, Plotz J 
(2007) Mouthing off about fish capture: jaw movement in pinnipeds reveals the real secrets of ingestion. Deep-Sea Res II 54:256-269

McConnell BJ, Chambers C, Fedak MA (1992) Foraging ecology of southern elephant seals in relation to the bathymetry and productivity of the Southern Ocean. Antarct Sci 4: 393-398

Miller PJO, Johnson MP, Tyack PL, Terray EA (2004) Swimming gaits, passive drag and buoyancy of diving sperm whales Physeter macrocephalus. J Exp Biol 207:1953-1967

Myers RA, Baum JK, Shepherd TD, Powers SP, Peterson CH (2007) Cascading effects of the loss of apex predatory sharks from a coastal ocean. Science 315:1846-1850

Nowacek DP, Johnson MP, Tyack PL, Shorter KA, McLellan WA, Pabst DA (2001) Buoyant balaenids: the ups and downs of buoyancy in right whales. Proc R Soc Lond B Biol Sci 268:1811-1816

Pace ML, Cole JJ, Carpenter SR, Kitchell JF (1999) Trophic cascades revealed in diverse ecosystems. Trends Ecol Evol 14:483-488

Page B, McKenzie J, Hindell MA, Goldsworthy SD (2005) Drift dives by male New Zealand fur seals (Arctocephalus forsteri). Can J Zool 83:293-300

Pinaud D, Weimerskirch H (2005) Scale-dependent habitat use in a long-ranging central place predator. J Anim Ecol 74:852-863

R Development Core Team (2007) R: a language and environment for statistical computing. R Foundation for Statistical Computing, Vienna

Rintoul SR, Hughes CW, Olbers D (2001) The Antarctic Circumpolar Current system. In: Siedler G, Church J, Gould J (eds) Ocean circulation and climate. Observing and modelling the global ocean. Academic Press, London, p 271-302

Sato K, Mitani Y, Cameron MF, Siniff DB, Watanabe Y, Naito $Y$ (2002) Deep foraging dives in relation to the energy depletion of Weddell seal (Leptonychotes weddellii) mothers during lactation. Polar Biol 25:696-702

Sato K, Mitani Y, Cameron MF, Siniff DB, Naito Y (2003) Factors affecting stroking patterns and body angle in diving Weddell seals under natural conditions. J Exp Biol 206:1461-1470

Schmidt-Nielsen K (1997) Animal Physiology: adaptation and enviroment. Cambridge University Press, Cambridge

Editorial responsibility: Rory Wilson,

Swansea, UK
Schreer JF, Testa JW (1995) Statistical classification of diving behavior. Mar Mamm Sci 11:85-93

Schreer JF, Testa JW (1996) Classification of Weddell seal diving behavior. Mar Mamm Sci 12:227-250

Schreer JF, Hines RJOH, Kovacs KM (1998) Classification of dive profiles: a comparison of statistical clustering techniques and unsupervised artificial neural networks. J Agric Biol Environ Stat 3:383-404

Simeone A, Wilson RP (2003) In-depth studies of Magellanic penguin (Spheniscus magellanicus) foraging: can we estimate prey consumption by perturbations in the dive profile? Mar Biol 143:825-831

> Slip DJ, Burton HR, Gales NJ (1992) Determining blubber mass in the southern elephant seal, Mirounga leonina, by ultrasonic and isotopic techniques. Aust J Zool 40:143-152

> Thomson RB, Butterworth DS, Boyd IL, Croxall JP (2000) Modelling the consequences of Antarctic krill harvesting on Antarctic fur seals. Ecol Appl 10:1806-1819

Tremblay Y, Roberts AJ, Costa DP (2007) Fractal landscape method: an alternative approach to measuring arearestricted searching behavior. J Exp Biol 210:935-945

Vogel S (1981) Life in moving fluids: the physical biology of flow. W Grant Press, Boston, MA

Watanabe Y, Baranov EA, Sato K, Naito Y, Miyazaki N (2006) Body density affects stroke patterns in Baikal seals. J Exp Biol 209:3269-3280

> Webb PM, Crocker DE, Blackwell SB, Costa DP, Leboeuf BJ (1998) Effects of buoyancy on the diving behavior of northern elephant seals. J Exp Biol 201:2349-2358

Weimerskirch H, Gault A, Cherel Y (2005) Prey distribution and patchiness: factors in foraging success and efficiency of wandering albatrosses. Ecology 86:2611-2622

Williams TM, Davis RW, Fuiman LA, Francis J and others (2000) Sink or swim: strategies for cost-efficient diving by marine mammals. Science 288:133-136

Wilson R, Peters G, Regel J, Gremillet D and others (1998) Short retention times of stomach temperature loggers in free-living seabirds - is there hope in the spring? Mar Biol 130:559-566

Wilson RP, Steinfurth A, Ropert-Coudert Y, Kato A, Kurita M (2002) Lip-reading in remote subjects: an attempt to quantify and separate ingestion, breathing and vocalisation in free-living animals using penguins as a model. Mar Biol $140: 17-27$

Submitted: January 23, 2008; Accepted: June 11, 2008

Proofs received from author(s): October 9, 2008 